Article

\title{
Post-Anthesis Mobilization of Stem Assimilates in Wheat under Induced Stress
}

\author{
Mian Faisal Nazir 1,2 ${ }^{10}$, Zareen Sarfraz ${ }^{2}$, Naimatullah Mangi ${ }^{2}$, , Muhammad Kausar Nawaz Shah ${ }^{1}$, \\ Talat Mahmood 1, Tahir Mahmood 1,2, Muhammad Shahid Iqbal 1,2,*(D), Muhammad Ishaq Asif Rehmani 3,*(D), \\ Mohamed El-Sharnouby ${ }^{4}$, Mohamed Khamees Aly Shabaan ${ }^{5}$, Sobhy Gharib Rizk Sorour ${ }^{5}$ \\ and Ayman EL Sabagh 5,*(D)
}

\section{check for} updates

Citation: Nazir, M.F.; Sarfraz, Z.; Mangi, N.; Nawaz Shah, M.K.;

Mahmood, T.; Mahmood, T.; Iqbal, M.S.; Ishaq Asif Rehmani, M.; El-Sharnouby, M.; Shabaan, M.K.A.; et al. Post-Anthesis Mobilization of Stem Assimilates in Wheat under Induced Stress. Sustainability 2021, 13 , 5940. https://doi.org/10.3390/ su13115940

Academic Editor: Roberto Mancinelli

Received: 23 April 2021

Accepted: 21 May 2021

Published: 25 May 2021

Publisher's Note: MDPI stays neutral with regard to jurisdictional claims in published maps and institutional affiliations.

Copyright: (c) 2021 by the authors. Licensee MDPI, Basel, Switzerland. This article is an open access article distributed under the terms and conditions of the Creative Commons Attribution (CC BY) license (https:/ / creativecommons.org/licenses/by/ $4.0 /)$.
1 Department of Plant Breeding and Genetics, PMAS Arid Agriculture University, Rawalpindi 46000, Pakistan; mfn121@hotmail.com (M.F.N.); knshah@uaar.edu.pk (M.K.N.S.); drtalat@uaar.edu.pk (T.M.); tahirmtaha@hotmail.com (T.M.)

2 State Key Laboratory of Cotton Biology, Institute of Cotton Research, Chinese Academy of Agricultural Sciences, Anyang 455000, China; zskpbg@hotmail.com (Z.S.); manginaimatullah2014@gmail.com (N.M.)

3 Department of Agronomy, Ghazi University, Dera Ghazi Khan 32200, Pakistan

4 Department of Biotechnology, College of Science, Taif University, Taif 21944, Saudi Arabia; m.sharnouby@tu.edu.sa

5 Department of Agronomy, Faculty of Agriculture, Kafrelsheikh University, Kafrelsheikh 33156, Egypt; mohamed_game19@yahoo.com (M.K.A.S.); sobhysor@yahoo.com (S.G.R.S.)

* Correspondence: shahidkooria@gmail.com (M.S.I.); mrehmani@gudgk.edu.pk (M.I.A.R.); ayman.elsabagh@agr.kfs.edu.eg (A.E.S.)

Abstract: Stem reserves in grain crops are considered important in grain filling under post-anthesis stress in the absence/low availability of photosynthetic assimilates. Considerable variation is present among genotypes for stem reserve translocation in wheat. Therefore, this study aimed to exploit the phenotypic variation for stem reserve translocation in wheat under control and chemically induced stress conditions. The phenotypic variation among six parents and their corresponding direct cross combinations was evaluated under induced stress conditions. The results signify the presence of considerable variation between treatments, genotypes, and treatment-genotype interactions. The parent LLR-20 depicted the highest translocation of dry matter and contribution of post-anthesis assimilates under induced-stress conditions. Similarly, cross combinations Nacozari $\times$ LLR22, Nacozari $\times$ LLR 20, Nacozari $\times$ Parula, Nacozari $\times$ LLR 21, LLR $22 \times$ LLR 21, and LLR $20 \times$ LLR 21 showed higher source-sink accumulation under induced-stress conditions. The selected parents and cross combinations can be further utilized in the breeding program to strengthen the genetic basis for stress tolerance in wheat.

Keywords: stem reserves; photosynthetic assimilates; abiotic stress; combining ability; translocation

\section{Introduction}

Pakistan is among the countries with the rising adversary of climate change [1] in terms of increasing temperatures and random rainfalls [2]. Achieving maximum yield under the climate change scenario is critical for sustainable agriculture [3]. Increased evapotranspiration with the increase in annual temperature has emerged as a natural hindrance in arid zones [4], resulting in reduced crop production. Wheat production, both in irrigated and rainfed areas, is hampered due to environmental stresses [5]. Therefore, it is pertinent to exploit existing germplasm for developing new cultivars tolerant to the changing environment $[6,7]$.

Terminal drought stress at the grain filling stage has been considered a major factor affecting the optimum yield [8]. Stabilizing grain yield under stress conditions is likely influenced by storage of photosynthetic assimilates and their efficiency remobilization $[9,10]$. Stem reserves are critically involved in yield enhancement by improving 
grain filling [11,12]. Generally, stem reserves are water-soluble carbohydrates [13], radially available for translocation to other plant parts. However, their ability to translocate is highly specific to the genotype and environmental conditions [14]. Previously published statistics have suggested a 50\% decrease in the mobilization of stem reserves in cereals, including wheat, under dryland conditions compared to irrigated conditions [15]. Furthermore, due to reduced photosynthesis after anthesis, current photosynthetic assimilates reduced, gradually affecting the grain filling [16]. Severe environmental stress may reduce grain filling, leaf desiccation, and reduced photosynthesis [17-19]. Genotypes with the ability to mobilize the stem reserve under stress conditions are likely to yield better [13]. Therefore, along with other breeding strategies to cope with climate change, breeding for stem reserves is important.

Wild progenitors, landraces, and obsolete accessions are excellent sources for cumulating desirable variation in cultivars [20]. Genotypes with the ability to translocate stem reserves as a carbon source for grain filling can play a crucial role in environmental stress conditions to overcome/minimize yield losses. The study was aimed to exploit local landraces of wheat for efficient utilization of stem reserves under induced senescence conditions. We performed a systematic study to evaluate local landraces, obsolete accessions, and F1 progeny under induced senescence as stress stimuli.

\section{Results}

We evaluated wheat genotypes under control and induced stress conditions for phenotypic traits related to stem reserve mobilization. The values of different plant traits of 21 genotypes, including 15 direct cross combinations and 6 parental lines, were subjected to a two-factor analysis of variance [21]. The results exhibited highly significant $(p<0.01)$ differences among all genotypes for studied traits (Table 1). Analysis of variance also showed significant differences among control and treated conditions. Similarly, genotype-treatment interaction was also found significant.

Table 1. Mean squares for six wheat varieties and fifteen F1 crosses.

\begin{tabular}{ccccccc}
\hline SOV & Df & DMA & DMM & TDM & TE & CPA \\
\hline Replication & 2 & $2334.381 \mathrm{~ns}$ & $2971.341 \mathrm{~ns}$ & $9122.198 \mathrm{~ns}$ & $3.133 \mathrm{~ns}$ & $7.41 \mathrm{~ns}$ \\
Treatment (T) & 1 & $243.056^{* *}$ & $38,006,177.7^{* *}$ & $10,549,093^{* *}$ & $11,600.643^{* *}$ & $43,260.51^{* *}$ \\
Error & 2 & 1811.937 & 278.167 & 2468.865 & 7.198 & 0.872 \\
Genotype (G) & 20 & $1,835,737.2^{* *}$ & $2,096,902.058^{* *}$ & $1,045,662^{* *}$ & $1160.817^{* *}$ & $2246.031^{* *}$ \\
T $\times$ G & 41 & $748.772^{* *}$ & $212,916.902^{* *}$ & $242,712.4^{* *}$ & $322.716^{* *}$ & $639.084^{* *}$ \\
Error & 80 & 1661.159 & 636.312 & 5210.865 & 4.009 & 5.298 \\
\hline
\end{tabular}

CPA, contribution of post-anthesis assimilate; DMA, total dry matter at anthesis (g); DMM, total dry matter at maturity (g); SOV, source of variation; TDM, translocation of dry matter $(\mathrm{g}) ; \mathrm{TE} \%$, translocation efficiency percentage. ${ }^{* *}$ Significant at $p<0.01$.

\section{Effect of Induced Stress}

The two-factor ANOVA suggested significant variation under control and induced stress conditions among different genotypes. To compartmentalize the phenotypic variation, we further analyzed the data for combining ability analysis. Analysis of variance for combining ability is presented in Table 2. A separate analysis for both control and induced stress treatment emphasized significant differences for general combining ability (GCA) and specific combining ability (SCA) for all the traits under study. A likelihood ratio (LR) test for homogeneity of variance depicted significant differences in error variance (Table 3). Therefore, it is speculated that heterogeneity is important for consideration in this experiment, and all analyses were performed supposing heterogeneity of variance between stress and non-stress/control conditions. For illustration, we report genotype means for the two experiments for different traits (Figure 1). Comparisons of mean values suggested non-significant differences for DMA (dry matter at anthesis); however, it took a toll, and dry matter reduced significantly at maturity (DMM) under induced stress conditions (Figure 1B). The differences in the dry matter at anthesis suggest considerable translocation 
under induced stress conditions and signify the importance of translocation under stress environments. Similarly, results for TE\% (translocation efficiency), CPA (contribution of pre-anthesis assimilates), and TDM (translocation of dry matter) depicted differential behavior under control and induced stress treatments (Figure 1C-E). The genotypes also showed significant variation for each trait.

A

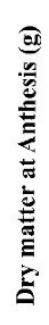

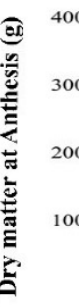

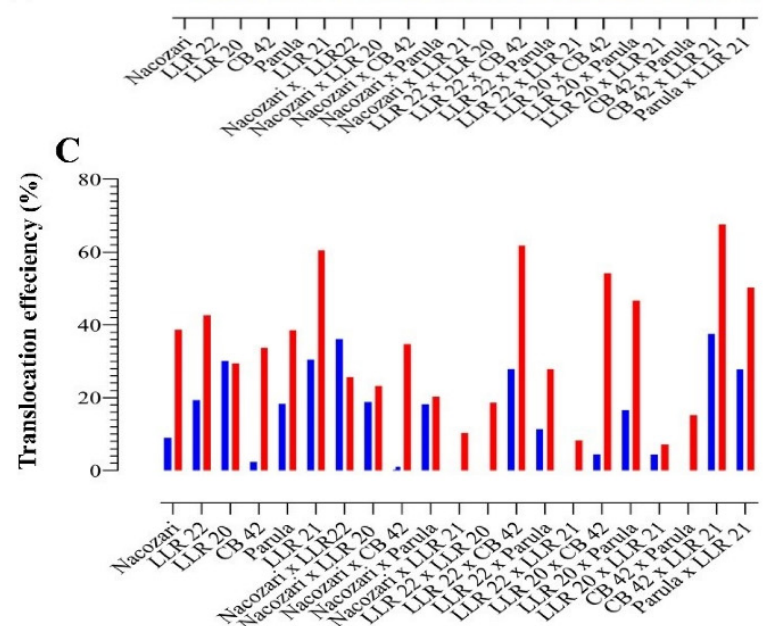

$\mathbf{B}$

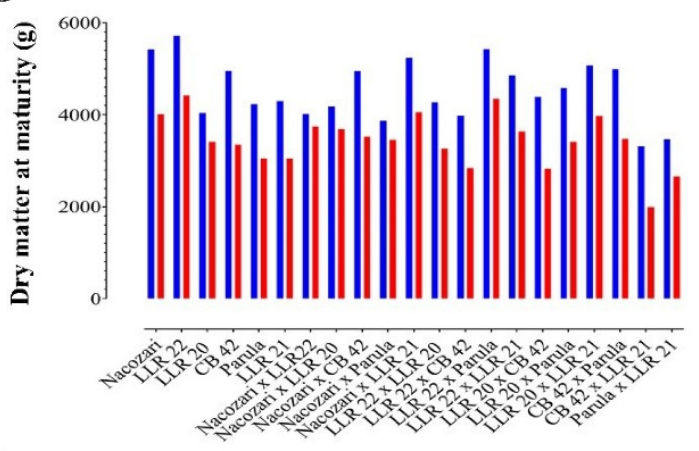

D总 100 丰

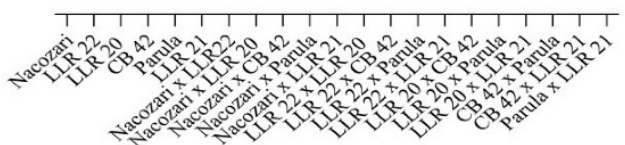

E
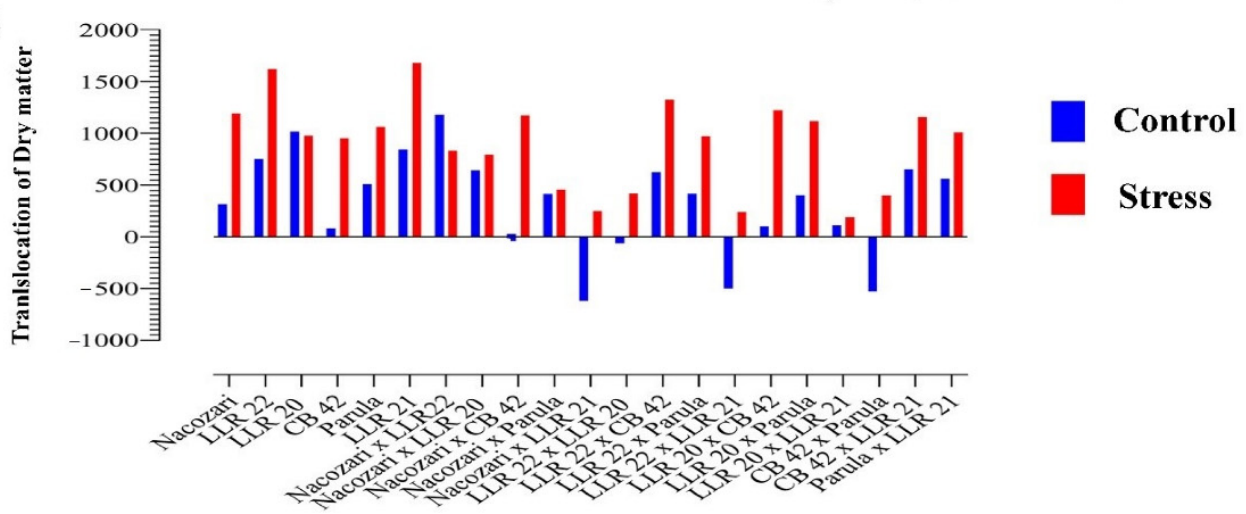

Figure 1. Mean values of 21 genotypes (5 parents and 16 direct crosses) under control and induced stress conditions: (A) genotype means for DMA (dry matter at anthesis); (B) genotype means for DMM (dry matter at maturity); (C) genotype means for TE\% (translocation efficiency percentage); (D) genotype means for CPA (contribution of pre-anthesis assimilates); (E) genotype means for TDM (translocation of dry matter). 
Table 2. ANOVA ( $\mathrm{F}=\mathrm{F}$-values and $p=p$-values) for combining ability.

\begin{tabular}{|c|c|c|c|c|c|c|c|c|c|c|c|c|c|c|}
\hline \multirow{2}{*}{\multicolumn{2}{|c|}{ SOV }} & \multirow{2}{*}{ Df } & \multicolumn{2}{|c|}{ TGW (g) } & \multicolumn{2}{|c|}{ DMA (g) } & \multicolumn{2}{|c|}{ DMM (g) } & \multicolumn{2}{|c|}{ TDM (g) } & \multicolumn{2}{|c|}{ TE $\%$} & \multicolumn{2}{|c|}{ CPA } \\
\hline & & & F & $p$ & $\mathbf{F}$ & $p$ & $\mathbf{F}$ & $p$ & F & $p$ & F & $p$ & F & $p$ \\
\hline \multirow{4}{*}{ Cont. } & Rep & 2 & 1.02 & $\mathrm{~ns}$ & 0.07 & ns & 5.26 & $* *$ & 1.77 & ns & 3.4 & 0.043 & 3.21 & $\mathrm{~ns}$ \\
\hline & Gen & 20 & 66.75 & $* * *$ & 1254.2 & $* * *$ & 2782.4 & $* * *$ & 478.6 & $* * *$ & 490.1 & $* * *$ & 658.4 & $* * *$ \\
\hline & GCA & 5 & 100.62 & $* * *$ & 1561.53 & $* * *$ & 1702.4 & $* * *$ & 171.21 & $* * *$ & 136.55 & $* * *$ & 379.5 & $* * *$ \\
\hline & SCA & 15 & 55.46 & $* * *$ & 1151.82 & $* * *$ & 3142.5 & $* * *$ & 581.16 & $* * *$ & 608.03 & $* * *$ & 751.42 & $* * *$ \\
\hline \multirow{4}{*}{ St } & Rep & 2 & 0.1 & ns & 1.59 & ns & 0.98 & ns & 1 & ns & 0.98 & 0.3849 & 0.34 & ns \\
\hline & Geno & 20 & 2609.16 & $* * *$ & 351.94 & $* * *$ & 1252.9 & $* * *$ & 63.84 & $* * *$ & 140 & $* * *$ & 202.06 & $* * *$ \\
\hline & GCA & 5 & 3986.5 & $* * *$ & 447.01 & $* * *$ & 2143 & $* * *$ & 16.03 & $* * *$ & 83.52 & $* * *$ & 58.63 & $* * *$ \\
\hline & SCA & 15 & 2150.05 & $* * *$ & 320.25 & $* * *$ & 956.01 & $* * *$ & 79.78 & $* * *$ & 158.9 & $* * *$ & 249.87 & $* * *$ \\
\hline
\end{tabular}

CPA, contribution of post-anthesis assimilate; DMA, total dry matter at anthesis (g); DMM, total dry matter at maturity (g); G, genotypes; GCA, general combining ability; Rep, replication; SCA, specific combining ability; SOV, source of variation; TDM, translocation of dry matter (g); TE\%, translocation efficiency percentage; TGW, 1000-grain weight (g). ${ }^{* *}$ Significant at $p<0.01 ;{ }^{* * *}$ Highly significant at $p<0.001$.

Table 3. Error variances of individual experiments for the five traits and LR test for homogeneity of variance.

\begin{tabular}{|c|c|c|c|c|c|c|c|}
\hline Experiment & & TGW (g) & DMA (g) & DMM (g) & TDM (g) & TE\% & CPA \\
\hline Control & & 0.68 & 739.47 & 467.69 & 1501.93 & 1.0299 & 1.6321 \\
\hline Induced Stress & & 0.0201 & 2582.85 & 804.93 & 8919.8 & 6.989 & 8.9604 \\
\hline LR-Test for Homogeneity & $x^{2}$ & 87.74 & 14.72 & 2.91 & 28.26 & 32.14 & 26.05 \\
\hline of Variance & $p$ & $<0.0001$ & 0.0001 & 0.0879 & $<0.0001$ & $<0.0001$ & $<0.0001$ \\
\hline
\end{tabular}

CPA, contribution of post-anthesis assimilate; DMA, total dry matter at anthesis (g); DMM, total dry matter at maturity (g); TDM, translocation of dry matter (g); TE\%, translocation efficiency percentage; TGW, 1000-grain weight (g).

To further understand the variation among genotypes, we performed F-tests (sequential, Type 1) and estimated the significance level of replicate-treatment, genotype, and genotype-treatment interaction. The results suggested significant treatment-genotype interaction for all traits except dry matter at anthesis (Table 4), signifying the influence of induced-stress treatment on gene action of the respective traits. Similarly, except DMA, all traits showed significant interaction for both the SCA and GCA effects (Table 4).

Table 4. F-tests (sequential, Type I) of effects for replicate-treatment, genotype, and genotype-treatment interaction in a joint analysis of both trials.

\begin{tabular}{|c|c|c|c|c|c|c|c|c|}
\hline SOV & Df & & TGW & DMA (g) & DMM (g) & TDM (g) & TE\% & CPA \\
\hline \multirow{2}{*}{ Replicate-Treatment } & \multirow{2}{*}{5} & $\mathrm{~F}$ & 897.38 & 0.68 & 11779.9 & 399.78 & 571.44 & 1610.19 \\
\hline & & $p$ & $<0.0001$ & 0.64 & $<0.0001$ & $<0.0001$ & $<0.0001$ & $<0.0001$ \\
\hline \multirow{2}{*}{ Genotype } & \multirow{2}{*}{20} & $\mathrm{~F}$ & 250.6 & 1105.09 & 3295.4 & 200.67 & 289.55 & 424.08 \\
\hline & & $p$ & $<0.0001$ & $<0.0001$ & $<0.0001$ & $<0.0001$ & $<0.0001$ & $<0.0001$ \\
\hline \multirow{2}{*}{ GCA } & \multirow{2}{*}{5} & $\mathrm{~F}$ & 402.6 & 1389.95 & 3430.09 & 23.87 & 77.72 & 50.77 \\
\hline & & $p$ & $<0.0001$ & $<0.0001$ & $<0.0001$ & $<0.0001$ & $<0.0001$ & $<0.0001$ \\
\hline \multirow{2}{*}{ SCA } & \multirow{2}{*}{15} & $\mathrm{~F}$ & 199.94 & 1010.14 & 3250.52 & 259.68 & 360.16 & 548.52 \\
\hline & & $p$ & $<0.0001$ & $<0.0001$ & $<0.0001$ & $<0.0001$ & $<0.0001$ & $<0.0001$ \\
\hline \multirow{2}{*}{ Genotype-Treatment } & \multirow{2}{*}{20} & $\mathrm{~F}$ & 28.87 & 0.45 & 334.61 & 46.58 & 80.49 & 120.67 \\
\hline & & $p$ & $<0.0001$ & 0.9749 & $<0.0001$ & $<0.0001$ & $<0.0001$ & $<0.0001$ \\
\hline \multirow{2}{*}{ GCA-Treatment } & \multirow{2}{*}{5} & $\mathrm{~F}$ & 21.75 & 0.2 & 532 & 52.95 & 102.95 & 165.38 \\
\hline & & $p$ & $<0.0001$ & 0.9631 & $<0.0001$ & $<0.0001$ & $<0.0001$ & $<0.0001$ \\
\hline \multirow{2}{*}{ SCA-Treatment } & \multirow{2}{*}{15} & $\mathrm{~F}$ & 31.25 & 0.54 & 268.81 & 44.47 & 73 & 105.77 \\
\hline & & $p$ & $<0.0001$ & 0.9099 & $<0.0001$ & $<0.0001$ & $<0.0001$ & $<0.0001$ \\
\hline
\end{tabular}

CPA, contribution of post-anthesis assimilate; DMA, total dry matter at anthesis (g); DMM, total dry matter at maturity (g); GCA, general combining ability; SCA, specific combining ability; SOV, source of variation; TDM, translocation of dry matter (g); TE\%, translocation efficiency percentage; TGW, 1000-grain weight (g). 
Stress resistance index (SRi) was calculated for each trait, as previously described by Piepho et al. [14]. Stress resistance index as interaction contrast, the pairwise difference between control and induced stress treatment for a specific trait, was compared against the average over genotypes. The results are presented in Table 5. Based on SRi, we estimated tolerant genotypes for each trait under study. For instance, cross combinations Nacozari $\times$ CB 42 and LLR $22 \times$ LLR 21 and parent CB 42 depicted tolerant behavior for TGW under induced stress conditions. Similarly, parent LLR20 showed relatively tolerant behavior for translocation of dry matter, while parents Nacozari, CB 42, and LLR 21 depicted negative SRi. The negative SRi depicted a stress-susceptible response. However, parents LLR22 and Paula depicted non-significant SRi, emphasizing the negligible role of stem reserve translocation under stress conditions. Cross combinations Nacozari $\times$ LLR22, Nacozari $\times$ Paula, Nacozari $\times$ LLR 20, Nacozari $\times$ LLR 21, LLR $20 \times$ LLR 21, and LLR $22 \times$ LLR 21 depicted higher accumulations of dry matter, i.e., tolerance behavior. In contrast, cross combinations Nacozari $\times$ CB 42, LLR $20 \times$ CB 42, LLR $22 \times$ CB 42, LLR $20 \times$ Paula, and CB $42 \times$ LLR 21 depicted susceptible behavior under stress conditions with negative SRi.

Table 5. Estimates of differences between control and drought treatment for contrast ("entry vs. all entries") with standard error (SE).

\begin{tabular}{|c|c|c|c|c|c|c|c|c|c|c|c|c|}
\hline \multirow[t]{2}{*}{ Genotype } & \multicolumn{2}{|c|}{ TGW (g) } & \multicolumn{2}{|c|}{ DMA (g) } & \multicolumn{2}{|c|}{ DMM (g) } & \multicolumn{2}{|c|}{ TE\% } & \multicolumn{2}{|c|}{ TDM } & \multicolumn{2}{|c|}{ CPA } \\
\hline & SRi & $p$ & SRi & $p$ & SRi & $p$ & SRi & $p$ & SRi & $p$ & SRi & $p$ \\
\hline Nacozari & -0.3 & 1.0 & 1.3 & 1.0 & 333.1 & $<0.0001$ & -312.9 & $<0.0001$ & -11.1 & $<0.0001$ & -7.4 & 0.0 \\
\hline Nacozari $\times$ LLR22 & -1.0 & 0.6 & 4.8 & 1.0 & -869.9 & $<0.0001$ & 969.9 & $<0.0001$ & 31.0 & $<0.0001$ & 36.8 & $<0.0001$ \\
\hline Nacozari $\times$ LLR 20 & 4.5 & $<0.0001$ & -16.9 & 1.0 & -643.8 & $<0.0001$ & 452.2 & $<0.0001$ & 15.5 & $<0.0001$ & 9.3 & $<0.0001$ \\
\hline Nacozari $\times$ CB 42 & 0.2 & 1.0 & 15.3 & 1.0 & 349.6 & $<0.0001$ & -637.7 & $<0.0001$ & -16.1 & $<0.0001$ & -54.5 & $<0.0001$ \\
\hline Nacozari $\times$ Paula & -0.6 & 1.0 & 3.0 & 1.0 & -713.1 & $<0.0001$ & 559.7 & $<0.0001$ & 17.9 & $<0.0001$ & 31.2 & $<0.0001$ \\
\hline Nacozari × LLR21 & -2.7 & $<0.0001$ & 7.2 & 1.0 & 85.0 & 0.0 & -305.2 & $<0.0001$ & 9.3 & $<0.0001$ & 24.9 & $<0.0001$ \\
\hline LLR 22 & -4.9 & $<0.0001$ & 31.0 & 1.0 & 211.0 & $<0.0001$ & -304.8 & $<0.0001$ & -4.4 & 0.2 & -7.1 & 0.0 \\
\hline LLR $22 \times$ LLR 20 & 1.4 & 0.1 & -53.3 & 0.9 & -95.3 & 0.0 & 102.6 & 0.8 & 0.6 & 1.0 & 8.7 & 0.0 \\
\hline LLR $22 \times$ CB 42 & 0.4 & 1.0 & 11.4 & 1.0 & 42.3 & 0.6 & -129.1 & 0.5 & -15.4 & $<0.0001$ & -3.3 & 0.8 \\
\hline LLR $22 \times$ Paula & -0.9 & 0.7 & -4.3 & 1.0 & -20.8 & 1.0 & 20.7 & 1.0 & 2.8 & 0.9 & 1.7 & 1.0 \\
\hline LLR $22 \times$ LLR 21 & 4.8 & $<0.0001$ & -22.5 & 1.0 & 127.3 & $<0.0001$ & -169.0 & 0.1 & 11.5 & $<0.0001$ & 12.7 & $<0.0001$ \\
\hline LLR 20 & -0.2 & 1.0 & 13.9 & 1.0 & -495.4 & $<0.0001$ & 647.5 & $<0.0001$ & 21.0 & $<0.0001$ & 4.3 & 0.4 \\
\hline LLR $20 \times$ CB 42 & -0.5 & 1.0 & 14.6 & 1.0 & 482.9 & $<0.0001$ & -571.5 & $<0.0001$ & -32.1 & $<0.0001$ & -27.9 & $<0.0001$ \\
\hline LLR $20 \times$ Paula & 3.9 & $<0.0001$ & 21.6 & 1.0 & 76.2 & 0.0 & -144.5 & 0.3 & -11.4 & $<0.0001$ & 0.3 & 1.0 \\
\hline LLR $20 \times$ LLR 21 & -1.7 & 0.0 & 18.8 & 1.0 & 0.3 & 1.0 & 521.5 & $<0.0001$ & 17.3 & $<0.0001$ & 29.9 & $<0.0001$ \\
\hline CB 42 & 5.6 & $<0.0001$ & -4.3 & 1.0 & 537.2 & $<0.0001$ & -307.6 & $<0.0001$ & -12.8 & $<0.0001$ & -25.1 & $<0.0001$ \\
\hline CB $42 \times$ Paula & -0.6 & 1.0 & -36.5 & 1.0 & 435.7 & $<0.0001$ & -364.3 & $<0.0001$ & 4.1 & 0.3 & 5.9 & 0.1 \\
\hline CB $42 \times$ LLR 21 & -2.1 & 0.0 & -28.5 & 1.0 & 228.5 & $<0.0001$ & 76.3 & 1.0 & -11.5 & $<0.0001$ & -15.0 & $<0.0001$ \\
\hline Paula & -0.3 & 1.0 & -22.9 & 1.0 & 80.4 & 0.0 & 23.8 & 1.0 & -1.3 & 1.0 & -16.0 & $<0.0001$ \\
\hline Paula $\times$ LLR 21 & -3.5 & $<0.0001$ & 1.3 & 1.0 & -305.0 & $<0.0001$ & 138.6 & 0.4 & -3.3 & 0.6 & 4.3 & 0.4 \\
\hline LLR 21 & -1.5 & 0.1 & 45.0 & 1.0 & 153.9 & $<0.0001$ & -266.3 & 0.0 & -11.3 & $<0.0001$ & -13.7 & $<0.0001$ \\
\hline SE & 0.5 & & 34.1 & & 21.1 & & 60.4 & & 1.7 & & 1.9 & \\
\hline
\end{tabular}

CPA, contribution of post-anthesis assimilate; DMA, total dry matter at anthesis (g); DMM, total dry matter at maturity (g); SRi, stress resistance index; TDM, translocation of dry matter (g); TE\%, translocation efficiency percentage; TGW, 1000-grain weight (g).

We further evaluated variance parameters and derived quantities to understand the random effects of genotypes. The results are presented in Table 6. The ratio (CR/DR) of correlated response to selection under control treatment and selection under stress treatment were taken into account for direct selection under stress treatment, as previously elaborated by [22]. The result shows that direct selection under treatment 2 is preferable for all traits except dry matter at anthesis (Table 6). 
Table 6. Variance parameter estimates, heritabilities, and correlated response (CR) ratio over direct response (DR) to selection for the six traits.

\begin{tabular}{|c|c|c|c|c|c|c|}
\hline SOV & TGW (g) & DMA (g) & DMM (g) & $\mathrm{TE} \%$ & TDM & CPA \\
\hline$\sigma_{g(\text { control })}^{2}$ & 14.9024 & $308,943.45$ & $433,260.52$ & $239,132.1$ & 167.9183 & 357.66478 \\
\hline$\sigma_{g(\text { drought stress })}^{2}$ & 17.4721 & $302,552.56$ & $335,651.14$ & $186,835.69$ & 323.94253 & 600.51176 \\
\hline$\rho_{g(\text { control }), g(\text { drought stress })}$ & 0.8016 & 1 & 0.8226291 & 0.6330897 & 0.5989808 & 0.5778774 \\
\hline$\sigma_{\rho}^{2}(\operatorname{control)}$ & 0.6800 & 696.74361 & 467.69211 & 1501.9254 & 1.0298581 & 1.632095 \\
\hline$\sigma_{e(\text { drought stress })}^{2}$ & 0.02010 & 2162.5795 & 804.93264 & 8919.8047 & 6.9890113 & 8.9604112 \\
\hline$H_{\text {control }}$ & 0.9850 & 0.9992488 & 0.9996403 & 0.9979108 & 0.9979598 & 0.9984812 \\
\hline$H_{\text {drought stress }}$ & 0.9996 & 0.9976231 & 0.9992013 & 0.9843355 & 0.9928597 & 0.9950509 \\
\hline$C R / D R$ & 0.7957 & 1.0008145 & 0.8228098 & 0.6374404 & 0.6005172 & 0.5788727 \\
\hline$\sigma_{G C A}^{2}$ & 1.4321 & 13,408 & 5930.75 & 885.84 & 0.00000 & 0.00 \\
\hline$\sigma_{S C A}^{2}$ & 10.0279 & 13,927 & 63,706 & 79,752 & 146.22 & 282.74 \\
\hline$\sigma_{G C A \times \text { treatment (control) }}^{2}$ & 0 & 6673.19 & 591.43 & 1541.84 & 0.0000 & 16.7078 \\
\hline$\sigma_{S C A \times \text { treatment (control) }}^{2}$ & 2.1136 & 53,856 & 38,929 & 45,475 & 24.2590 & 56.1866 \\
\hline$\sigma_{G C A \times \text { treatment (drought stress) }}^{2}$ & 0 & 4532.98 & 4049.25 & 146.24 & 8.3914 & 0.00 \\
\hline$\sigma_{S C A \times \text { treatment (drought stress) }}^{2}$ & 4.3910 & 46,997 & 13,982 & 18,935 & 167.32 & 315.65 \\
\hline
\end{tabular}

CPA, contribution of post-anthesis assimilate; DMA, total dry matter at anthesis (g); DMM, total dry matter at maturity (g); TDM, translocation of dry matter (g); TE\%, translocation efficiency percentage; TGW, 1000-grain weight (g).

\section{Discussion}

Wheat is a major grain crop due to its nutritional value and wide acceptability worldwide $[14,23,24]$. However, adversities associated with climate change are major challenges to meet the ever-increasing demand of food supply with the increasing population [25-27]. Therefore, breeding for stress tolerance has been the focus of many studies during the past few decades. There are many techniques to understand and exploit stress mechanisms, mainly specific to the stress conditions, i.e., water-stress [28], salt-stress [29,30], nutrient-stress [31], or temperature-stress [19,32-34]. Stem reserves, as water-soluble carbohydrates, are the major source of carbon for grain filling under stress conditions [35]. Furthermore, after anthesis, when photosynthesis is reduced [16], stem reserves provide a source for grain filling. However, plants' response towards stem reserve translocation is highly specific and varies considerably between genotypes [11]. Therefore, it is important to understand the existing variation in the germplasm and utilize it for further breeding programs. This study aimed to provide an efficient method for screening the germplasm for stress tolerance under chemically induced stress conditions, which can be utilized as a generalized response towards stress.

The experiment consisted of two treatments: treatment 1 was kept as control under rainfed conditions, and treatment 2 was chemically induced stress treatment. The methodology used for chemical desiccation of plants was adapted from Blum et al. [11]. Potassium iodide was used as a chemical desiccant. Previously reported statistics suggested stem reserve translocation as an important indicator for selection under stress conditions [36,37]. Therefore, we selected six parents and their direct crosses to screen for variation in genotypes regarding stem reserve translocations. Similar studies have been conducted to exploit the stem reserve for the reproductive sink in grain crops, viz., wheat [36,38], maize [39,40], and rice [41,42]. Chemical desiccation provides excellent stimuli for stress, and resulting responses can be categorized as generalized stress responses [41,43].

Presented results depicted statistically significant variation among genotypes in response to chemically-induced stress. These results are in line with previous reports suggesting genotype-specific responses towards induced stress in different crops [44-47]. After the development of semi-dwarf genotypes with increased yield, the post-green revolution era resulted in reduced accumulation of water-soluble carbohydrates in the stem [44]. Therefore, it is pertinent to exploit the natural variation present in wild relatives and obsolete accessions. We used six parental lines, including four local landraces 
and two obsolete accessions. Parental lines and direct cross combinations (21 in total) depicted (supported by the presented data analysis) differential responses under control and induced-stress treatment. Furthermore, results indicated heterogeneity, previously explained by Resende et al. [48], as an important consideration between the control and induced-stress conditions. F-statistics also suggested significant variation for all the traits corresponding to genotypes, GCA, SCA, genotype-treatment interaction, GCA-treatment interaction, and SCA-treatment interaction.

The stress tolerance index, a relative measure of stress, is an important indicator for selecting specific traits under stress conditions [14]. Our results depicted considerable variation among genotypes for their stress tolerance indices for different traits. This variation can be further utilized in breeding programs to exploit stem reserve translocation in wheat to cope with devastating effects of stress, especially in rainfed areas where terminal stress is a common environmental attribute. The design and analysis can also be utilized in breeding programs for efficient germplasm screening for future breeding.

\section{Materials and Methods}

\subsection{Plant Material}

The experimental materials comprised six wheat local landraces and obsolete accessions, viz., Nacozari, LLR-20, LLR-21, LLR-22, CB-42, Paula, and 15 F1 populations (only direct crosses). The lines were previously screened and identified for stem reserve translocation. The screening was done for the total dry matter at anthesis ( $g)$, total dry matter at maturity $(\mathrm{g})$, translocation of dry matter $(\mathrm{g})$, translocation efficiency percentage, the contribution of post-anthesis assimilate associated with stem reserve mobilization, and other yield-related morphological characters. The screening study was conducted during the wheat growing season (planted in autumn and harvested in spring).

\subsection{Induced Senescence as Stress Stimuli}

The experiment for combining ability studies was planted in the next growing season. All the experiments were performed in the experimental area, Department of Plant Breeding and Genetics, PMAS Arid Agriculture University Rawalpindi, Pakistan.

All the F1 hybrids and their parents were arranged in randomized complete block design in field conditions, and the experiment was conducted in triplicate. Two sets of this experiment were sown under rainfed conditions, with one kept as control while the other was treated with potassium iodide at $50 \%$ anthesis stage to create chemical desiccation. Two seeds hole ${ }^{-1}$ were sown with the help of a dibbler in rows $(5 \mathrm{~m}$ each) with row $\times$ plant spacing of $15 \mathrm{~cm} \times 15 \mathrm{~cm}$. After germination, thinning was done to maintain one seedling hill $^{-1}$ after germination. All other cultural and agronomic practices (seed treatment, time of sowing, fertilization, pest and disease control, thinning, etc.) were kept uniform following local recommendations to maintain stress-free crop throughout the growing season. At maturity, ten guarded plants from each replication were randomly selected for recording data for the traits.

\subsection{Data Collection}

The data were recorded for the traits (listed below) at the required stage from ten guarded plants randomly selected from each replication.

\subsubsection{Areal Plant Biomass Treated}

At maturity, ten un-thrashed plants were randomly harvested from each experimental unit treated with potassium iodide and weighed using an electric balance (grams). Some derived parameters were also calculated related to biomass and translocation of stem reserves according to the method described by Papakosa and Gagianas [49]:

Dry matter mobilization $=D M A-D M M$ 
where dry matter mobilization is in mg plant $^{-1}$, DMA is dry matter at anthesis, and DMM is dry matter at maturity.

$$
\text { Translocation efficiency }(\%)=\frac{\text { Dry Matter Mobilization }}{D M A} \times 100
$$

where DMA is dry matter at anthesis.

Contribution of assimilates to grain $(\%)=($ Mobilization of dry matter/grain weight $) \times 100$

$$
\text { Assimilate contribution to grain }(\%)=\frac{\text { Dry Matter Mobilization }}{\text { Grain Weight }} \times 100
$$

\subsubsection{Areal Plant Biomass for Control}

The areal plant biomass of plants grown under rainfed conditions was measured according to the method for areal plant biomass for treated plants.

\subsection{Statistical Analysis}

The data collected for all the traits were subjected to analysis of variance according to Steel et al. [50]. AOV-function in R-software was employed to perform analysis of variance (R Foundation for Statistical Computing, Vienna, Austria https:/ / www.r-project.org/, accessed on 10 December 2020). LR tests for homogeneity of variance were conducted according to Stehlik et al. [51]. Further analysis to understand the variation in dry matter translocation as stress response was estimated using the model suggested by Piepho et al. [14].

\section{Conclusions}

The variation among genotypes can be further utilized in the breeding programs to exploit stem reserve translocation in wheat to cope with devastating effects of stress, especially in rainfed areas where terminal stress is a common environmental attribute. The design and analysis can also be utilized in breeding programs for efficient germplasm screening for future breeding. The selected parents and cross combinations can be further utilized in the breeding program to strengthen the genetic basis for stress tolerance in wheat.

Author Contributions: Conceptualization, M.K.N.S., T.M. (Talat Mahmood), M.F.N., Z.S., and M.S.I.; experimentation, M.F.N., Z.S., N.M., M.K.N.S., and M.S.I.; data collection and analysis, M.F.N., Z.S., T.M. (Talat Mahmood), T.M. (Tahir Mahmood), M.I.A.R., A.E.S., and M.S.I.; writing—original draft preparation, M.F.N. and M.S.I.; writing—review and editing, M.E.-S., M.K.A.S., S.G.R.S., A.E.S., M.F.N., M.S.I. and M.I.A.R. funding acquisition: M.E.-S., A.E.S. All authors have read and agreed to the published version of the manuscript.

Funding: This work was supported by Project number (TURSP-2020/139), Taif University, Taif, Saudi Arabia.

Institutional Review Board Statement: Not Applicable.

Informed Consent Statement: Not Applicable.

Data Availability Statement: Data is available from the authors at reasonable request without undue reservations.

Acknowledgments: We acknowledge Department of Plant Breeding and Genetics, PMAS Arid Agriculture University, Rawalpindi, Pakistan, for providing plant materials, research facilities and other resources for the current study. This work was supported by Project number (TURSP-2020/139), Taif University, Taif, Saudi Arabia.

Conflicts of Interest: The authors declare no conflict of interest. 


\section{References}

1. Chaudhry, Q.U.Z. Climate Change Profile of Pakistan; Asian Development Bank: Mandaluyong, Philippines, 2017.

2. Piepho, H.P.; Nazir, M.F.; Qamar, M.; Rattu, A.U.R.; Hussain, M.; Ahmad, G.; Ahmad, J.; Laghari, K.B.; Vistro, I.A.; Kakar, M.S. Stability analysis for a countrywide series of wheat trials in Pakistan. Crop Sci. 2016, 56, 2465-2475. [CrossRef]

3. Sarkar, D.; Kar, S.K.; Chattopadhyay, A.; Rakshit, A.; Tripathi, V.K.; Dubey, P.K.; Abhilash, P.C. Low input sustainable agriculture: A viable climate-smart option for boosting food production in a warming world. Ecol. Indic. 2020, 115, 106412. [CrossRef]

4. Adnan, S.; Ullah, K.; Khan, A.H.; Gao, S. Meteorological impacts on evapotranspiration in different climatic zones of Pakistan. J. Arid Land 2017, 9, 938-952. [CrossRef]

5. Mardeh, A.S.-S.; Ahmadi, A.; Poustini, K.; Mohammadi, V. Evaluation of drought resistance indices under various environmental conditions. Field Crops Res. 2006, 98, 222-229. [CrossRef]

6. Kamal, K.; Raizada, M.N.; Navabi, A. Recent Progress in germplasm evaluation and gene mapping to enable breeding of drought-tolerant wheat. Front. Plant Sci. 2020, 11, 1149.

7. Atlin, G.N.; Cairns, J.E.; Das, B. Rapid breeding and varietal replacement are critical to adaptation of cropping systems in the developing world to climate change. Glob. Food Secur. 2017, 12, 31-37. [CrossRef]

8. Salem, K.F.M.; Röder, M.S.; Börner, A. Identification and mapping quantitative trait loci for stem reserve mobilisation in wheat (Triticum aestivum L.). Cereal Res. Commun. 2007, 35, 1367-1374. [CrossRef]

9. Hussain, S.; Saleem, M.F.; Iqbal, J.; Ibrahim, M.; Atta, S.; Ahmad, T.; Rehmani, M.I.A. Exogenous application of abscisic acid may improve the growth and yield of sunflower hybrids under drought. Pak. J. Agric. Sci. 2014, 51, 49-58.

10. Moayedi, A.A.; Boyce, A.N.; Barakbah, S.S. Influence of water deficit during different growth and developmental stages on the contribution of stored pre-anthesis assimilates to grain in selected durum and bread wheat genotypes. Aust. J. Basic Appl. Sci. 2009, 3, 4408-4415.

11. Blum, A. Improving wheat grain filling under stress by stem reserve mobilisation. Euphytica 1998, 100, 77-83. [CrossRef]

12. Bidinger, F.; Musgrave, R.; Fischer, R. Contribution of stored pre-anthesis assimilate to grain yield in wheat and barley. Nature 1977, 270, 431-433. [CrossRef]

13. Saint Pierre, C.; Trethowan, R.; Reynolds, M. Stem solidness and its relationship to water-soluble carbohydrates: Association with wheat yield under water deficit. Funct. Plant Biol. 2010, 37, 166-174. [CrossRef]

14. Piepho, H.-P.; Nazir, M.F.; Nawaz Shah, M.K. Design and analysis of a trial to select for stress tolerance. Commun. Biometry Crop Sci. 2016, 11, 1-9.

15. Hussain, S.; Rivandi, A. Molecular breeding for drought tolerance in plants: Wheat perspective. Proc. Pak. Acad. Sci. 2007, 44, 35-62.

16. Ding, L.; Wang, K.; Jiang, G.; Liu, M.; Niu, S.; Gao, L. Post-anthesis changes in photosynthetic traits of maize hybrids released in different years. Field Crops Res. 2005, 93, 108-115. [CrossRef]

17. Shao, C.; Shen, L.; Qiu, C.; Wang, Y.; Qian, Y.; Chen, J.; Ouyang, Z.; Zhang, P.; Guan, X.; Xie, J. Characterizing the impact of high temperature during the grain filling on phytohormone levels, enzyme activities and metabolic profiles of the early indica-rice variety. Plant Biol. 2021. [CrossRef]

18. Seleiman, M.F.; Al-Suhaibani, N.; Ali, N.; Akmal, M.; Alotaibi, M.; Refay, Y.; Dindaroglu, T.; Abdul-Wajid, H.H.; Battaglia, M.L. Drought stress impacts on plants and different approaches to alleviate its adverse effects. Plants 2021, 10, 259. [CrossRef]

19. Rehmani, M.I.A.; Wei, G.; Hussain, N.; Ding, Q.; Li, G.; Liu, Z.; Wang, S.; Ding, D. Yield and quality responses of two indica rice hybrids to post-anthesis asymmetric day and night open-field warming in lower reaches of Yangtze River delta. Field Crops Res. 2014, 156, 231-241. [CrossRef]

20. Nazir, M.F.; Jia, Y.; Ahmed, H.; He, S.; Iqbal, M.S.; Sarfraz, Z.; Ali, M.; Feng, C.; Raza, I.; Sun, G. Genomic insight into differentiation and selection sweeps in the improvement of upland cotton. Plants 2020, 9, 711. [CrossRef]

21. Marascuilo, L.A.; Levin, J.R. The simultaneous investigation of interaction and nested hypotheses in two-factor analysis of variance designs. Am. Educ. Res. J. 1976, 13, 61-65. [CrossRef]

22. Atlin, G.; Baker, R.; McRae, K.B.; Lu, X. Selection response in subdivided target regions. Crop Sci. 2000, 40, 7-13. [CrossRef]

23. Ali, M.H.S.; Akhtar, N.; Saif-Ur-Rehman, A.S.; Nadeem, M.; Tanveer, M.H. Genetic analysis of Pakistani wheat germplasm for yield contributing traits under normal and heat stressed conditions. Pak. J. Agric. Sci. 2020, 57, 1503-1508.

24. Sarfraz, Z.; Shah, M.M.; Iqbal, M.S.; Nazir, M.F.; Fatima, S.A. Identification of valuable traits through molecular and morphological markers in diploid wheat. Pak. J. Biotechnol. 2020, 17, 71-77. [CrossRef]

25. Khan, I.; Lei, H.; Khan, A.; Muhammad, I.; Javeed, T.; Khan, A.; Huo, X. Yield gap analysis of major food crops in Pakistan: Prospects for food security. Environ. Sci. Pollut. Res. 2021, 28, 7994-8011. [CrossRef]

26. Farrukh, M.U.; Bashir, M.K.; Hassan, S.; Adil, S.A.; Kragt, M.E. Mapping the food security studies in India, Pakistan and Bangladesh: Review of research priorities and gaps. Glob. Food Secur. 2020, 26, 100370. [CrossRef]

27. Nazir, M.F.; Mahmood, T.; Shah, M.K.N.; Sarfraz, Z.; Ali, W.; Metlo, M.A.U.; Iqbal, M.S. Inheritance studies for morphophysiological traits in wheat under rainfed condition. Pak. J. Biotechnol. 2019, 16, 105-113.

28. Sun, Y.; Wang, C.; Chen, H.Y.; Ruan, H. Response of plants to water stress: A meta-analysis. Front. Plant Sci. $2020,11,978$. [CrossRef] 
29. Yasir, T.A.; Khan, A.; Skalicky, M.; Wasaya, A.; Rehmani, M.I.A.; Sarwar, N.; Mubeen, K.; Aziz, M.; Hassan, M.M.; Hassan, F.A.S.; et al. Exogenous Sodium Nitroprusside Mitigates Salt Stress in Lentil (Lens culinaris Medik.) by Affecting the Growth, Yield, and Biochemical Properties. Molecules 2021, 26, 2576. [CrossRef]

30. Samah, M.A.; Aiad, M.A.; Khatab, I.A. Genetic diversity and phenotypic association with salinity tolerance in Egyptian barley cultivars using SRAP markers. J. Environ. Agric. Sci. 2017, 13, 51-56.

31. Shah, S.H.; Houborg, R.; McCabe, M.F. Response of chlorophyll, carotenoid and SPAD-502 measurement to salinity and nutrient stress in wheat (Triticum aestivum L.). Agronomy 2017, 7, 61. [CrossRef]

32. Hebbar, K.; Neethu, P.; Sukumar, P.A.; Sujithra, M.; Santhosh, A.; Ramesh, S.; Niral, V.; Hareesh, G.; Nameer, P.O.; Prasad, P. Understanding physiology and impacts of high temperature stress on the progamic phase of coconut (Cocos nucifera L.). Plants 2020, 9, 1651. [CrossRef] [PubMed]

33. Sattar, A.; Iqbal, M.M.; Areeb, A.; Ahmed, Z.; Irfan, M.; Shabbir, R.N.; Aishia, G.; Hussain, S. Genotypic variations in wheat for phenology and accumulative heat unit under different sowing times. J. Environ. Agric. Sci. 2015, 2, 8.

34. Zhang, Y.; Pan, J.; Huang, X.; Guo, D.; Lou, H.; Hou, Z.; Su, M.; Liang, R.; Xie, C.; You, M. Differential effects of a post-anthesis heat stress on wheat (Triticum aestivum L.) grain proteome determined by iTRAQ. Sci. Rep. 2017, 7, 1-11. [CrossRef] [PubMed]

35. Schittenhelm, S.; Langkamp-Wedde, T.; Kraft, M.; Kottmann, L.; Matschiner, K. Effect of two-week heat stress during grain filling on stem reserves, senescence, and grain yield of European winter wheat cultivars. J. Agron. Crop Sci. 2020, 206, 722-733. [CrossRef]

36. Ehdaie, B.; Alloush, G.; Waines, J. Genotypic variation in linear rate of grain growth and contribution of stem reserves to grain yield in wheat. Field Crops Res. 2008, 106, 34-43. [CrossRef]

37. Borrell, A.K.; Incoll, L.; Dalling, M.J. The influence of the $R h t_{1}$ and $R h t_{2}$ alleles on the deposition and use of stem reserves in wheat. Ann. Bot. 1993, 71, 317-326. [CrossRef]

38. Ehdaie, B.; Alloush, G.; Madore, M.; Waines, J. Genotypic variation for stem reserves and mobilization in wheat: II. Postanthesis changes in internode water-soluble carbohydrates. Crop Sci. 2006, 46, 2093-2103. [CrossRef]

39. Setter, T.L.; Meller, V.H. Reserve carbohydrate in maize stem: [14C] glucose and [14C] sucrose uptake characteristics. Plant Physiol. 1984, 75, 617-622. [CrossRef]

40. Andrade, F.H.; Ferreiro, M.A. Reproductive growth of maize, sunflower and soybean at different source levels during grain filling. Field Crops Res. 1996, 48, 155-165. [CrossRef]

41. Wang, G.-Q.; Hao, S.-S.; Gao, B.; Chen, M.-X.; Liu, Y.-G.; Yang, J.-C.; Ye, N.-H.; Zhang, J.-H. Regulation of gene expression in the remobilization of carbon reserves in rice stems during grain filling. Plant Cell Physiol. 2017, 58, 1391-1404. [CrossRef]

42. Fu, J.; Huang, Z.; Wang, Z.; Yang, J.; Zhang, J. Pre-anthesis non-structural carbohydrate reserve in the stem enhances the sink strength of inferior spikelets during grain filling of rice. Field Crops Res. 2011, 123, 170-182. [CrossRef]

43. Blum, A.; Mayer, J.; Golan, G. Chemical desiccation of wheat plants as a simulator of post-anthesis stress: II. Relations to drought stress. Field Crops Res. 1983, 6, 149-155. [CrossRef]

44. Salem, K.F.; Elabsawy, E.A.; Aldahak, L.; Elshamy, H. Evaluation of stem reserve mobilization in Egyptian bread wheat (Triticum aestivum L.) genotypes and F1 hybrids under post-anthesis chemical desiccation stress. J. Genet. Environ. Resour. Conserv. 2021, 9 , 176-182.

45. Tarawneh, R.A.; Szira, F.; Monostori, I.; Behrens, A.; Alqudah, A.M.; Thumm, S.; Lohwasser, U.; Röder, M.S.; Börner, A.; Nagel, M. Genetic analysis of drought response of wheat following either chemical desiccation or the use of a rain-out shelter. J. Appl. Genet. 2019, 60, 137-146. [CrossRef]

46. Gare, S.; Wagh, R.; Ingle, A.; Soni, N. Effect of temperature on stem reserve mobilization for grain development in wheat. J. Pharmacogn. Phytochem. 2018, 7, 1119-1123.

47. Dodig, D.; Kandić, V.; Zorić, M.; Nikolić-Đorić, E.; Nikolić, A.; Mutavdžić, B.; Perović, D.; Šurlan-Momirović, G. Comparative kernel growth and yield components of two-and six-row barley (Hordeum vulgare) under terminal drought simulated by defoliation. Crop Pasture Sci. 2019, 69, 1215-1224. [CrossRef]

48. Resende, M.D.V.d. Software Selegen-REML/BLUP: A useful tool for plant breeding. Crop Breed. Appl. Biotechnol. 2016, 16, 330-339. [CrossRef]

49. Papakosta, D.K.; Gagianas, A. Nitrogen and dry matter accumulation, remobilization, and losses for Mediterranean wheat during grain filling. Agron. J. 1991, 83, 864-870. [CrossRef]

50. D'Steel, R.G.; Torrie, J.H. Principles and Procedures of Statistics: A Biometrical Approach; McGraw-Hill: New York, NY, USA, 1986.

51. Stehlik, M.; Wagner, H. Exact likelihood ratio testing for homogeneity of the exponential distribution. Commun. Stat. Simul. Comput. 2011, 40, 663-684. [CrossRef] 